\title{
A importância da evolução do uso do solo como geoindicador para o planejamento do Ecoturismo em Unidades de Conservação: aplicação no Parque Estadual da Pedra Branca (RJ)
}

\section{Rodrigo Silva da Conceição, Nadja Maria Castilho da Costa, Vivian Castilho da Costa}

\section{RESUMO}

As atividades de ecoturismo vêm sendo amplamente difundidas, praticadas e associadas aos ecossistemas das áreas legalmente protegidas, através da contemplação e contato com os seus recursos naturais. Os denominados geoindicadores podem ser entendidos como ferramentas de avaliação de condições e tendências, como uma alternativa para o estudo do ecoturismo sustentável. O Parque Estadual da Pedra Branca (PEPB), localizado na zona oeste do Rio de Janeiro, abrange a área do Maciço da Pedra Branca acima da cota altimétrica de 100 metros e abarca a maior floresta urbana do mundo. Nas últimas décadas, vem recebendo pressões originadas dos processos de uso e ocupação em seu entorno, relacionados, em grande parte, à expansão urbana. Este trabalho objetiva avaliar a evolução do uso do solo no PEPB como um dos geoindicadores para o desenvolvimento do ecoturismo, considerando a "floresta" como a categoria de uso mais importante, onde as práticas de lazer na natureza são efetivamente desenvolvidas. Para sua avaliação adotou-se como unidade de medição, o percentual de perda da categoria floresta com relação às demais categorias de uso do solo, em distintos períodos. Foram utilizadas as bases de dados de uso do solo de 1984, 1992 e 2001 (levantamentos realizados pela Secretaria de Meio Ambiente do Município do Rio de Janeiro - SMAC), tratadas no programa ArcGis, as quais subsidiaram as análises de monitoria ambiental realizadas no SAGA (Sistema de Análise Geo-Ambiental), bem como os mapeamentos de atrativos ecoturísticos e o buffer de 100 metros de seu entorno. Como principal resultado constatou-se a diminuição de floresta de $64,56 \%$ para $46,52 \%$ no período de $1984-2001$. Através do cruzamento entre os mapas de uso do solo e atrativos ecoturísticos verificou-se que, no PEPB, a maioria dos atrativos $(42,86 \%)$ encontra-se na categoria de uso "Floresta" e que a sua gradual redução poderá comprometer a manutenção dos recursos físico-bióticos que atraem os visitantes à área protegida.

PALAVRAS-CHAVE: Geoindicador; Unidade de Conservação; Uso do Solo. 
A importância da evolução do uso do solo como geoindicador para o planejamento do Ecoturismo em Unidades de Conservação: aplicação no Parque Estadual da Pedra Branca (RJ).

\section{The importance of the evolution of soil use as geoindicator to Ecotourism planning in Protected Areas - application in Parque Estadual da Pedra Branca, RJ, Brazil}

\section{ABSTRACT}

The activities of ecotourism have been widely spread out, practised and associated to ecosystems of the areas legally protected, through the contemplation and contact with its natural resources. The so-called geoindicators can be understood as tools of assessment of conditions and tendencies, as an alternative to the study of sustainable ecotourism. The State Park of Pedra Branca (PEPB), located in the west zone of Rio de Janeiro, encloses the area of the Pedra Branca Massif over the altimetric quote of 100 meters and includes the biggest urban forest in the world. In the last few decades, the area has received constant pressures from the processes of use and occupation in its boundary, related, to a large extent, to the urban expansion. The objective of this work is to evaluate the evolution of the soil use in the PEPB as one of the geoindicators for the development of the ecotourism, considering the "forest" as the category of the most important use, where the practices of leisure in the nature are effectively developed. It was adopted, as an assessment unit of measurement, the percentage of loss of the category forest with regards to the remaining categories of soil use, in different periods. The databases of soil use from 1984, 1992 and 2001 have been used (surveys carried out by the Department of Environment of the City of Rio De Janeiro - SMAC), treated in the ArcGis program, which has subsidized the analyses of environmental monitoring in a software called SAGA (System of GeoEnvironmental Analysis), as well as the mappings of attractive areas for ecotourism and the buffer of 100 meters of its boundary. As a result, the reduction of forest from $64,56 \%$ for $46,52 \%$ was evidenced in the period of $1984-2001$. Using data crossing between maps of soil use and ecotourism attractions, it was verified that, in PEPB, the majority of the attractions $(42,86 \%)$ is found in the category "Forest" and that its gradual reduction might compromise the maintenance of the physical-biotic resources which attracts the visitors to the protected area.

KEYWORDS: Geoindicator; Protect Area, Use of the Ground.

\section{Introdução}

O Parque Estadual da Pedra Branca (PEPB), localizado na zona oeste do município do Rio de Janeiro, situa-se no Maciço da Pedra Branca, que abarca a maior floresta urbana do mundo. O maciço possui terras nas Áreas de Planejamento (AP's) 4 e 5 da cidade, que reúnem as mais elevadas taxas de crescimento demográfico do 
município do Rio de Janeiro e configuram zonas de expansão urbana.

No PEPB são crescentes a visitação e a prática de atividades turísticas, e especificamente ecoturísticas. Suas trilhas, atrativos naturais e histórico-culturais, localizados em meio a remanescentes de Mata Atlântica possuem uma visitação crescente. Nos últimos sete anos, apesar da unidade ainda não possuir plano de manejo, foi construída uma infraestrutura de apoio à visitação, que reúne: museu, centro de visitação, áreas de lazer, entre outras, presentes em sua sede (Rio Grande) e sub-sedes (Camorim, Rio da Prata e Piraquara), localizadas próximas aos bairros da Taquara, Jacarepaguá, Barra da Tijuca, Campo Grande e Realengo.

Contudo, apesar da gestão do Parque estar criando mecanismos voltados ao uso público, ainda não há uma planificação das atividades voltadas ao ecoturismo, com base em preceitos e práticas sustentáveis. Toda e qualquer prática relacionada às atividades humanas e à conservação ambiental envolve a necessidade do planejamento, seja em uma perspectiva de direcionar ações voltadas ao potencial e sustentabilidade destas práticas, seja pela necessidade de se avaliar seus impactos sobre os recursos físico-bióticos. De acordo com Costa (2008a) a avaliação dos aspectos geográficos de uma determinada área irá conduzir ao conhecimento das potencialidades locais, bem como dos fatores limitantes às práticas ecoturísticas.

Neste contexto, o objetivo deste trabalho é avaliar a importância do geoindicador de evolução do uso do solo em Unidade de Conservação urbana, com base em sua aplicação (bem como parâmetros a ele relacionados, tal qual o de área de atrativos) no PEPB, através da utilização de Sistema de Informação Geográfica, com o intuito de auxiliar e apoiar à decisão das alternativas mais viáveis de planejamento ecoturístico, desta que é a maior unidade de conservação da cidade do Rio de Janeiro.

\section{Ecoturismo e Planejamento Ambiental}

O termo ecoturismo se traduz em experiências de apreciação e contato com a natureza, se aproveitando dos recursos naturais e dos vários ecossistemas das áreas legalmente protegidas. Entretanto, na maioria das vezes, é realizado de maneira predatória e inadequada, havendo a necessidade de ordenamento das atividades, a partir da compreensão do valor que determinados atributos ecoturísticos (recursos do meio físico e biótico) apresentam, bem como de avaliação contínua e sistemática de seu desempenho, no contexto social, econômico e político (COSTA et al, 2009).

O conceito de ecoturismo vem sendo usado com vários significados. Logo, alguns questionamentos são pertinentes e necessários ao desenrolar do planejamento e da prática sustentável: $\mathrm{O}$ que é o ecoturismo? Será que o que se é discutido em relação ao ecoturismo está considerando seu desenvolvimento dentro das premissas básicas do que se entende como seu verdadeiro conceito? Quais são os fatores físico-ambientais, sociais e culturais que permitem a prática efetiva do ecoturismo? Estas são algumas questões importantes a serem levadas em conta no processo de planejamento das atividades. 
A importância da evolução do uso do solo como geoindicador para o planejamento do Ecoturismo em Unidades de Conservação: aplicação no Parque Estadual da Pedra Branca (RJ).

Integrado à noção de sustentabilidade e desenvolvimento local e regional, o ecoturismo é conceituado por diversos autores como uma solução para o uso adequado de ambientes naturais visando, inclusive, a sua conservação. Sua prática está relacionada ao deslocamento de pessoas aos espaços naturais delimitados e protegidos (e/ou controlados) oficialmente pelo Estado, em parceria com associações locais e ONG's. Pressupõe a utilização controlada da área conservada com planejamento de uso sustentável de seus recursos naturais e culturais, por meio de estudos de impacto ambiental, monitoramento e avaliação constante (dentre outras diretrizes), através de planos de manejo e sistemas de gestão responsável (BENI, 2001; FILETTO, 2007).

Cintra (2004) e Costa (2008a) ressaltam ser fundamental que o planejamento e a gestão do desenvolvimento turístico sejam realizados com responsabilidade, usando de estratégias e ferramentas adequadas à manutenção, em todas as suas dimensões, da qualidade dos recursos que promovem o turismo e o sustentam.

O ecoturismo brasileiro tem sido desenvolvido, em sua grande maioria, nas Unidades de Conservação (UCs), onde os problemas de planejamento e gestão são evidentes e crescentes. Os recursos naturais nelas existentes são, em geral, pouco conhecidos. Raras são as áreas protegidas que "usam" seus recursos ecoturísticos em sua total potencialidade (COSTA, 2008a, p. 18).

Segundo Christofoletti (1999), o termo planejamento abarca uma ampla gama de atividades, podendo-se distinguir as categorias de planejamento estratégico (se relaciona com as tomadas de decisão, a longo e médio prazos, envolvendo um conjunto de pesquisas, discussões, negociações, etc.) e operacional (iniciativas e atividades de controle que se encontram conectadas com a implementação dos planos a serem executados), e ainda usar critérios de grandeza espacial (planejamento local, regional, nacional, entre outros), ou de setores de atividades (planejamento urbano, rural, ambiental, econômico, etc.). Segundo Santos (2004), planejar é estar a serviço de interesses públicos por meio de um ordenamento das atividades humanas. Conforme Xavier-da-Silva (2001, p. 21), especificamente, "o planejamento ambiental é um processo no qual são executados o levantamento e o diagnóstico das condições ambientais com o objetivo de otimizar o uso dos recursos ambientais disponíveis".

A pesquisa e o monitoramento das atividades ecoturísticas e do uso do solo a elas associadas constituem etapas de suma importância no processo de gestão do uso público em uma área legalmente protegida. O saber gerado pela pesquisa científica e tecnológica é insumo para a formulação de políticas públicas. O monitoramento objetiva informar sobre a qualidade ambiental, assegurando ao ambiente a qualidade compatível com seus usos desejáveis. Pode ser realizado por meio de tecnologias sofisticadas ou simples, com indicadores complexos ou simplificados (RIBEIRO, 1998). 


\section{O uso de geoindicadores e sua importância}

Um conjunto de indicadores adequadamente estabelecidos pode ser considerado como uma das mais efetivas técnicas para se acompanhar todas as fases de um planejamento ecoturístico. Possibilita avaliar as condições de produção e consumo (da prática ecoturística) atuais, e analisar, no decorrer do tempo, a sua sustentabilidade. Indicadores, em termos gerais, são "ferramentas constituídas por uma ou mais variáveis que, associadas, através de diversas formas, revelam significados mais amplos sobre os fenômenos a que se referem" (IBGE, 2008).

Segundo Bellen (2007, p. 43), "[...] os indicadores podem comunicar ou informar sobre o progresso em direção a uma determinada meta, como por exemplo, o desenvolvimento sustentável [...]". Segundo este mesmo autor, as principais funções dos indicadores são: avaliação de condições e tendências; comparação entre lugares e situações; avaliação de condições e tendências em relação às metas e aos objetivos; prover informações de advertência e antecipar futuras condições e tendências.

Os denominados "geoindicadores" provém de uma proposta inicialmente articulada para se medir fenômenos e processos ligados à escala geológica/ geomorfológica, objetivando avaliações ambientais.

Berger (1997) avalia que, o conceito de geoindicadores reúne ferramentas normativas em geomorfologia, hidrologia, geoquímica, e outras áreas em um formato útil a profissionais ambientais e administradores. $\mathrm{O}$ autor criou uma lista de geoindicadores associada às mudanças abióticas, aos sistemas biológicos e geológicos afetados por influências humanas, com melhor compreensão das mudanças ambientais.

Tavares et al. (2007) entendem que o reconhecimento e caracterização dos eventos responsáveis pelas mudanças na paisagem e nos processos naturais que podem resultar em degradação ambiental dependem do ambiente em estudo. Sendo assim, os geoindicadores variam de caso a caso, não só em função do interesse específico do estudo em desenvolvimento, mas também em função das características do ambiente avaliado e da dinâmica de seus processos.

O reconhecimento das mudanças ambientais tem importantes implicações para o desenvolvimento sustentável, a ética ambiental e a compreensão do meio ambiente. Geoindicadores podem ser um bom instrumento para melhorar as pesquisas interdisciplinares, focalizando as mudanças naturais e induzidas pelo homem na paisagem, sendo um caminho para a conexão com outros assuntos ambientais, econômicos e sociais (REGO NETO, 2003, p. 110).

A proposta que se apresenta é a de usar esses geoindicadores no contexto do planejamento ecoturístico e dar visibilidade à importância desta prática, assim como destacar como eles podem nortear os órgãos gestores, no sentido de direcionar as ações e até mesmo proporcionar a integração. 
A importância da evolução do uso do solo como geoindicador para o planejamento do Ecoturismo em Unidades de Conservação: aplicação no Parque Estadual da Pedra Branca (RJ).

Considera-se ainda como um ponto importante, não só o planejamento ecoturístico, mas as ferramentas a serem utilizadas nesse planejamento. Através da proposta de mensuração e avaliação de indicadores deve-se realizar um levantamento do que existe em relação às informações e os mapeamentos nos órgãos públicos. As bases cartográficas (em papel e/ou digital) são formas de se visualizar os geoindicadores. A ferramenta ideal para espacializar de forma ordenada e georreferenciada os geoindicadores é o geoprocessamento.

\section{Geoprocessamento: SIG, análise e monitoramento ambiental}

Os indicadores podem e devem ser aplicados através de geoprocessamento. De acordo com Filetto (op. cit), os indicadores são elementos chave que devem ser levados em consideração nos diversos tipos de monitoramento ambiental, podendo ser viabilizado através do uso de análise espacial. Daí o uso da terminologia geoindicadores.

Segundo Câmara et al (2000), o objetivo principal do geoprocessamento é fornecer ferramentas computacionais para que os diferentes analistas (considerando os diversos atores sociais envolvidos na produção espacial) determinem as evoluções espacial e temporal de um fenômeno geográfico e as interrelações entre diferentes fenômenos.

Xavier-da-Silva (2001, p. 2) considera geoprocessamento como "um conjunto de técnicas computacionais que opera sobre base de dados (que são registros de ocorrências) georreferenciados, para transformar em informação (que é um acréscimo de conhecimento) relevante".

As ferramentas computacionais para geoprocessamento, chamadas de Sistemas de Informação Geográfica (SIG's), permitem realizar análises complexas, integrar dados e criar bancos de dados georreferenciados. (CÂMARA et al., 2000). Assim, os SIG's podem ser vistos como um tipo bastante particular de sistema de suporte à tomada de decisão, oferecendo mecanismos para a manipulação e análise de dados georreferenciados frente a uma necessidade, para planejamento, controle e gestão do território. Assim, o uso desse instrumental tecnológico contribui no processo de [re]produção do espaço geográfico, uma vez que são utilizadas como meio de orientação.

Mais especificamente, os SIG's são ferramentas potencialmente indicadas para a construção e tratamento da informação nas diversas fases de um planejamento, bem como da gestão territorial. Costa (2008b, p. 155) indica que:

A informação espacial é ferramenta essencial para desenvolver e rever planos e estratégias, além de possibilitar a análise e monitoramento dos recursos naturais, processos ecológicos e usos. Deve contribuir ainda, para alcançar os objetivos de criação da UC e para sua gestão, direcionados à conservação ecológica.

A análise e o monitoramento da informação podem ser realizados utilizando diversos tipos de dados e técnicas disponíveis. O monitoramento da informação em uma UC é caracterizado como sendo "a realização de observações sistemáticas nas condições dos recursos naturais, a fim de detectar mudanças e tendências para direcionar as ações de manejo e controle" (COSTA, op. cit.). 


\section{Área de estudo}

O Maciço da Pedra Branca é circundado pelas baixadas litorâneas de Jacarepaguá e Sepetiba, e pode ser dividido em três vertentes: vertente oeste (voltada para os bairros de Campo Grande, Barra de Guaratiba e Guaratiba); vertente leste (voltada para os bairros da Taquara, Jacarepaguá, Barra da Tijuca, Vargem Grande, Vargem Pequena, Recreio e Grumari); e vertente norte (voltada para os bairros de Bangu, Realengo e Senador Camará). A vertente leste está voltada para os bairros que compõem a Área de Planejamento 4 da cidade, e as vertentes norte e oeste estão voltadas para os bairros da distinta Área de Planejamento 5 (Figura 1).

O Parque Estadual da Pedra Branca, com uma área total de 12,5 mil hectares, corresponde a todo o maciço montanhoso acima da cota altimétrica de 100 metros, conforme lei estadual (Lei $\mathrm{N}^{\circ}$. 2377 de 28/06/74). O Parque abriga uma exuberante floresta que, em grande parte, ainda se mantém com espécies nativas da Mata Atlântica, em diferentes estágios sucessionais. A área protegida foi criada então com o objetivo de se preservar tal bioma, assim como os mananciais que abastecem a região, como as represas do Camorim e do Pau da Fome, construções e ruínas de grande interesse histórico, como o antigo aqueduto e sedes de fazendas coloniais.

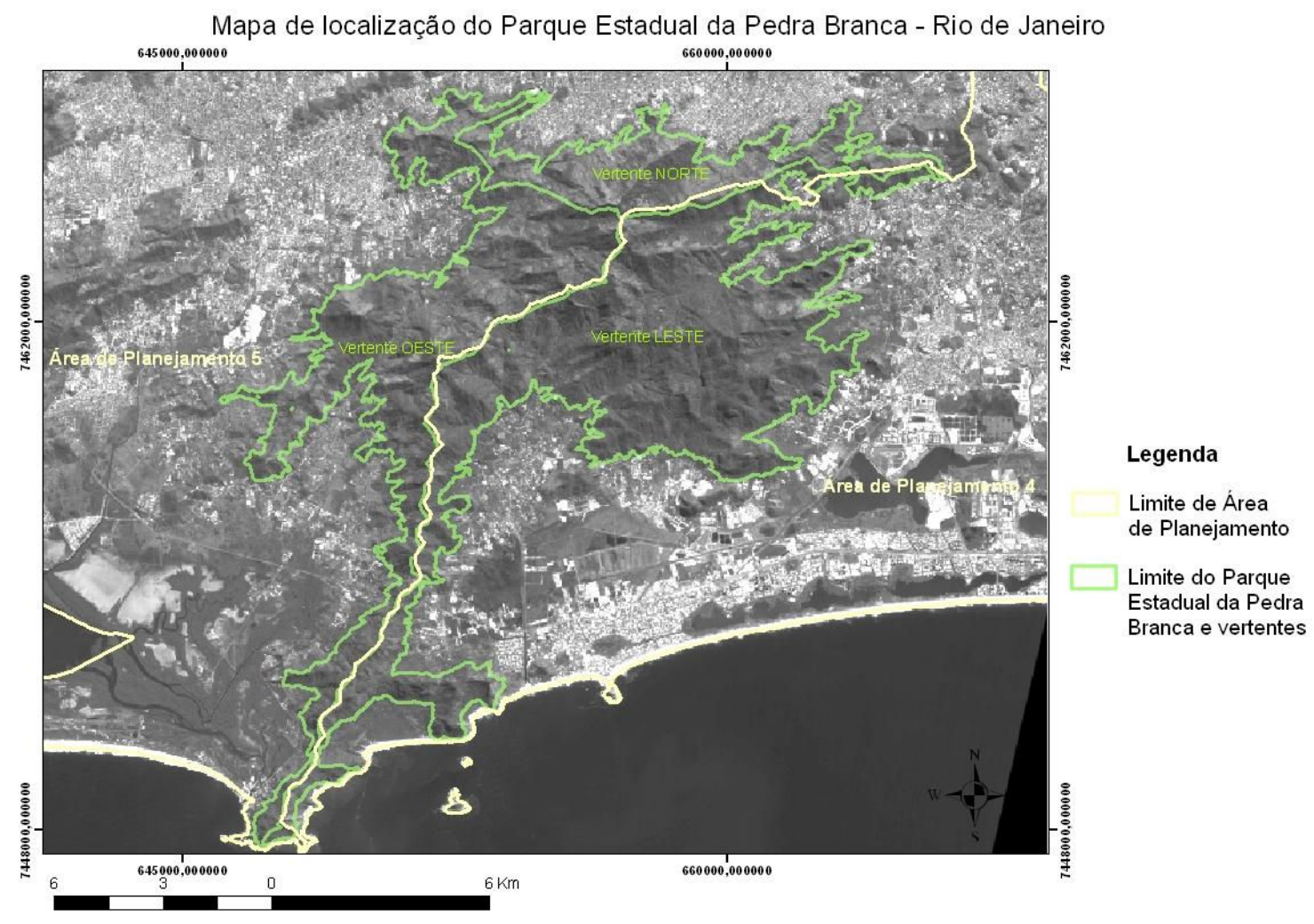

Figura 1 - Mapa de localização do PEPB.

Base de dados GEA (Grupo de Estudos Ambientais - UERJ) e IPP (Instituto Pereira Passos - Prefeitura do Rio de Janeiro) e Imagem ALOS-Prism (2008) / LAGEPRO - Laboratório de Geoprocessamento/ Instituto de Geografia / UERJ. 
A importância da evolução do uso do solo como geoindicador para o planejamento do Ecoturismo em Unidades de Conservação: aplicação no Parque Estadual da Pedra Branca (RJ).

Na cidade do Rio de Janeiro, verifica-se atualmente o processo de espraiamento da mancha urbana em direção à zona oeste da cidade (onde se localiza o PEPB), indicando um maior crescimento populacional proporcionado pela expansão da urbanização dessas áreas. Dada a caracterização social da cidade com grandes desigualdades, seu veemente processo de expansão e densificação urbana, assim como um quadro físico-natural marcado por áreas ambientalmente frágeis, urge a chamada crise ambiental na cidade.

A área protegida do maciço da Pedra Branca sofre intensa pressão urbana, devido à proximidade da metrópole. Problemas com desapropriação, ocupação ilegal e favelização, além de atividades de crime ambiental tais como a caça, incêndios e as plantações de banana, afligem o Parque. A intensa pressão imobiliária é verificada por meio do crescimento de condomínios de luxo (a exemplo dos Condomínios Camorim e Calharins com casas que passam do limite do Parque) e de favelas, situados entre as cotas de 60 e 100 metros do Maciço da Pedra Branca, muitos no interior do Parque e próximos à sede e sub-sedes (Figura 2). Tais ocupações desordenadas, em sua maioria, vêm comprometendo a qualidade dos recursos ambientais, a exemplo dos mananciais (recursos hídricos) poluídos pela falta de infraestrutura (pois o esgotamento sanitário é através do sistema de fossa ou diretamente jogado nos rios).

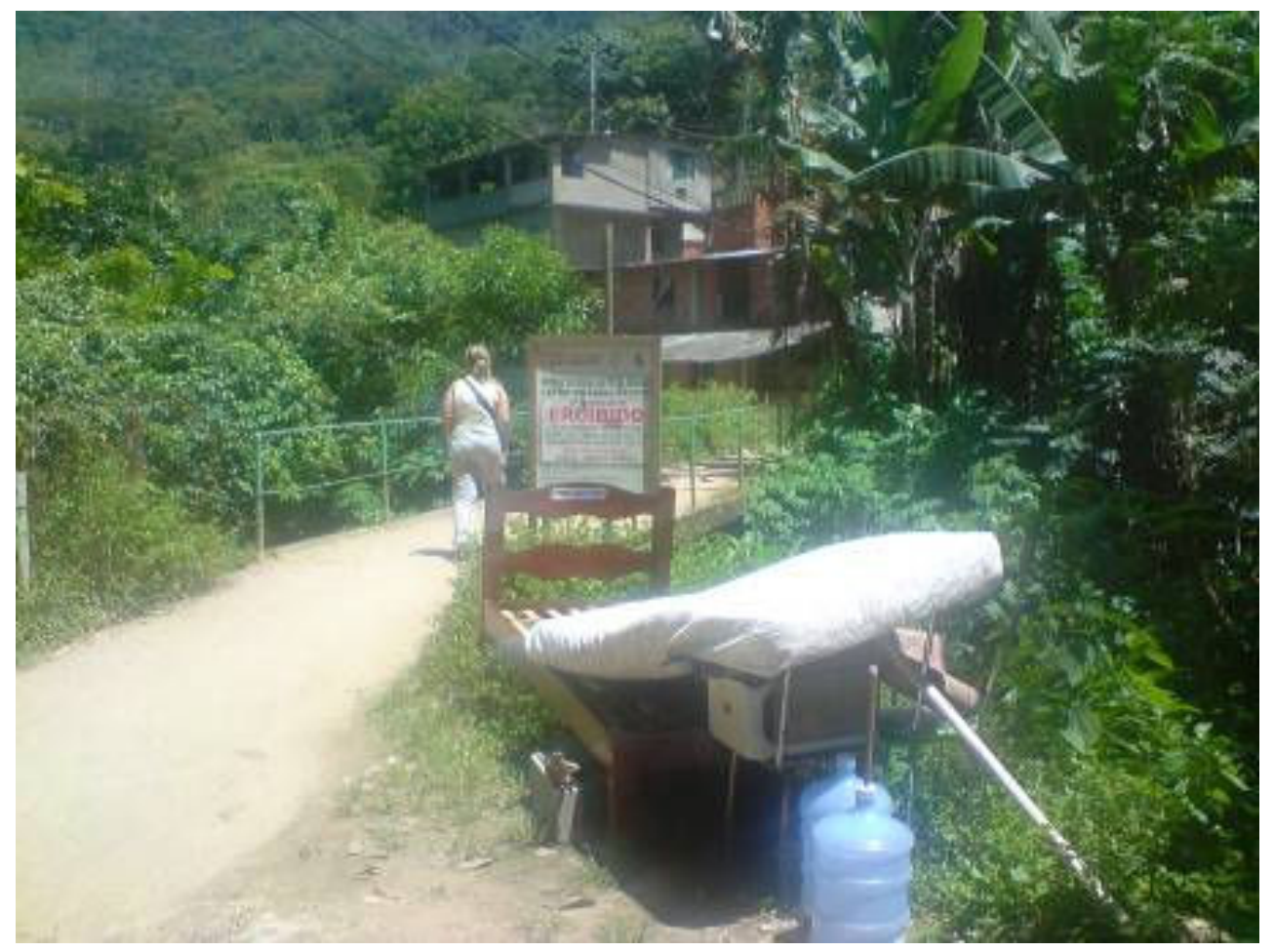

Figura 2 - Ocupação irregular às margens do Rio Grande, no interior do PEPB. Observa-se, no primeiro plano, lixo e entulho acumulado na entrada da comunidade, e ao fundo a placa com indicação de proibição de atividades poluidoras.

Foto: GEA, 2009. 
A redução da cobertura vegetal é ocasionada pelos diversos desmatamentos, seja para construção de casas ou para a expansão de culturas de subsistência, como o plantio de bananas (Figura 3) e atividades agropastoris, em que são comuns ocorrências de queimadas para limpeza de terrenos e renovação de pastagem.

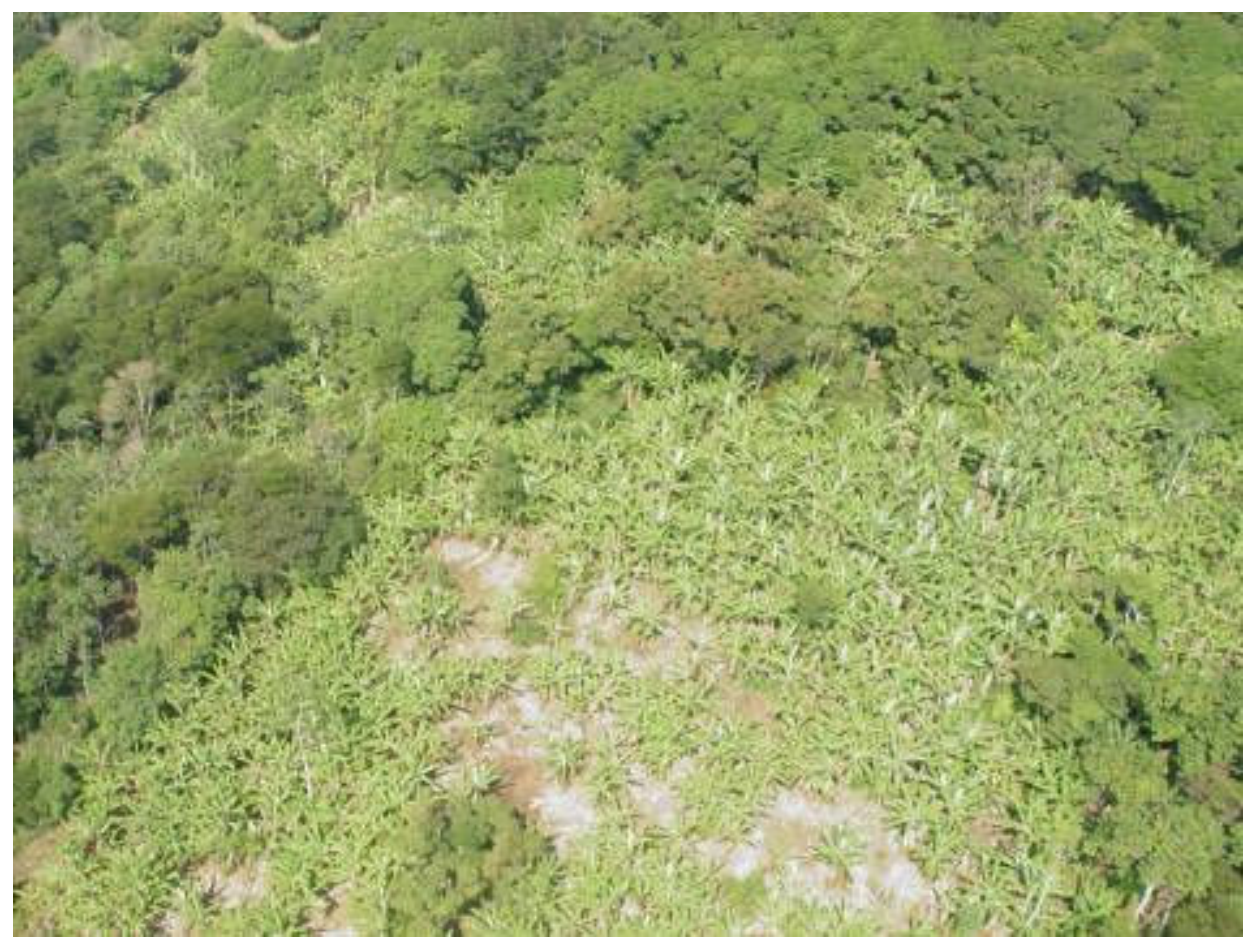

Figura 3 - Cultura de banana na vertente Leste (bairro de Grumari). Foto: GEA, 2008.

Logo, em relação às pressões sobre a base de recursos naturais, o PEPB tipifica uma área protegida sujeita a fortes impactos decorrentes da relação entre o uso do solo e as demandas de conservação da biodiversidade, em função do crescimento populacional, da ocupação desordenada (de baixa e alta renda) e de seus impactos sobre o patrimônio natural, tendendo a gerar um contexto sócio-ambiental complexo, caracterizado pelos mais diversos conflitos (HORTA et al., 2008).

\section{Materiais e métodos}

Em um primeiro momento, foram revistas informações disponibilizadas pela Prefeitura da Cidade do Rio de Janeiro (PCRJ), através do Instituto Pereira Passos (IPP) - órgão vinculado à Secretaria Municipal de Urbanismo (SMU), e da Secretaria Municipal de Meio Ambiente (SMAC). Conforme consta na publicação "Mapeamento e Caracterização do uso das terras e cobertura vegetal no Município do Rio de Janeiro entre os anos de 1984 e 1999" (PCRJ, 2000), o mapeamento do uso do solo no muni- 
A importância da evolução do uso do solo como geoindicador para o planejamento do Ecoturismo em Unidades de Conservação: aplicação no Parque Estadual da Pedra Branca (RJ).

cípio vem sendo promovido pela SMAC desde a década de 1980 (especificamente nos anos de 1984, 1988, 1992, 1996, 1999 e 2001). A partir das bases de dados em formato shape ( ${ }^{*}$ shp - ESRI) pode-se espacializar as informações da área do PEPB, por meio das ferramentas de análise de recorte (clipper) e buffer do ArcGis 9 (Figura 4 ), isolando somente o uso do solo no PEPB nos anos selecionados (1984, 1992 e 2001 - intervalos de cerca de 8 anos) para o monitoramento, bem como a área de proximidades de atrativos (100 metros).

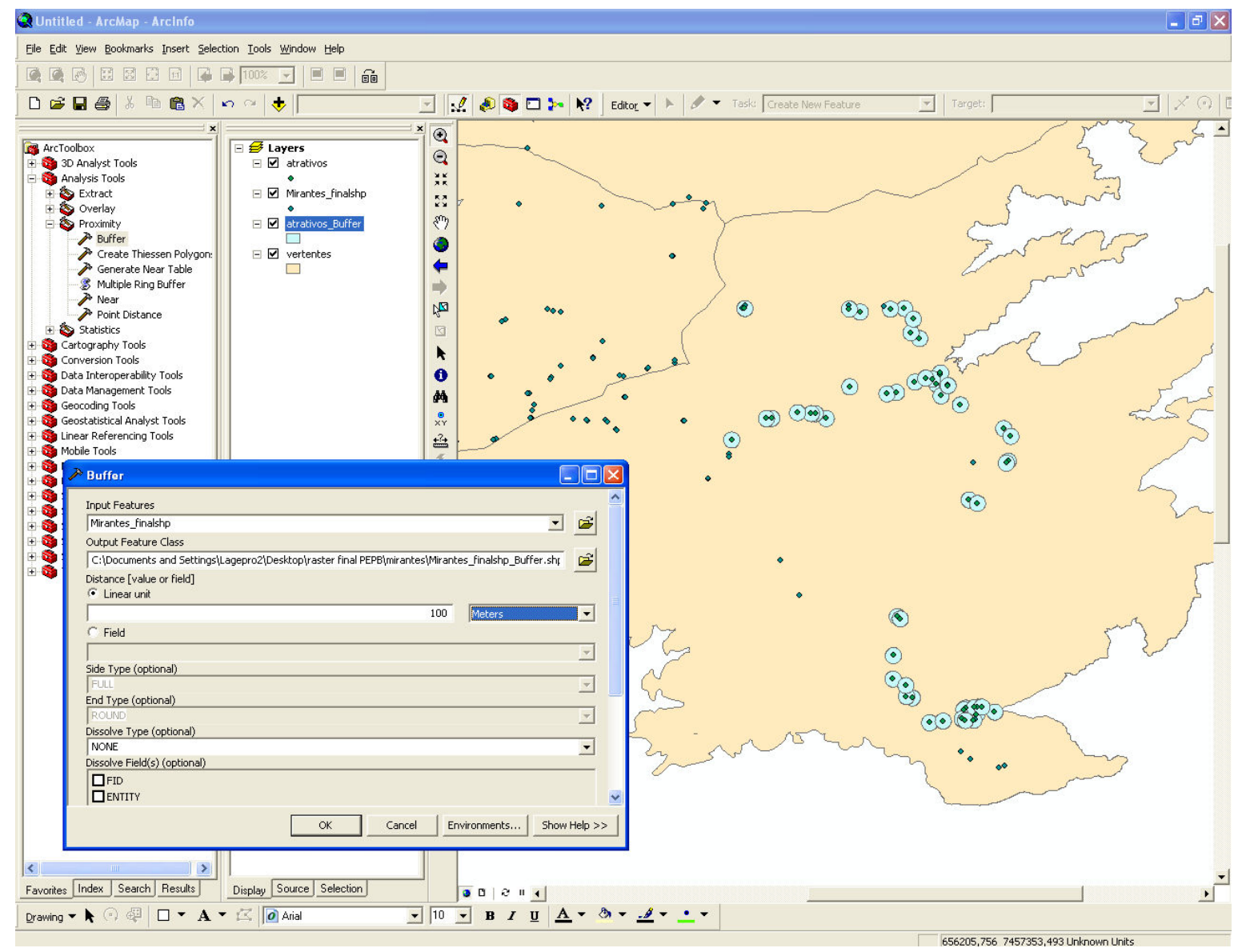

Figura 4 - Tela do ArcGis: utilização da ferramenta de buffer, a partir da base de atrativos no PEPB.

Através da exportação dos dados vetoriais (via ArcGis) para o formato *tiff (de figura), iniciou-se o processo de rasterização junto ao programa Vista-SAGA (LAGEOP, 2007). Objetivando-se o acompanhamento das mudanças da categoria "floresta", foram realizadas as seguintes análises: monitoria ambiental dos tipos simples e múltipla, utilizando-se os cartogramas de uso do solo; e assinatura ambiental dos mapas de uso do solo, buffer de atrativos e do mapa resultante da monitoria. 
A função de monitoria ambiental pode ser definida como um acompanhamento de alterações ambientais de diversas naturezas que tenham significância em uma determinada aplicação. As monitorias constituem uma forma de obter conhecimento sobre agentes modificadores do ambiente e propiciar apoio à busca de soluções para os problemas resultantes. As monitorias podem ser executadas em duas fases: simples e múltipla (MARINO, 2005).

A chamada monitoria simples pode ser feita através da comparação da ocorrência da mesma característica ambiental ao longo de duas ocasiões registradas e contidas nos dados inventariados (Figura 5). Esta estrutura de monitoria permite definir, imediatamente, as seguintes instâncias: os locais onde a característica não existia na primeira ocasião e continua sem existir na segunda; os locais onde a característica deixou de existir; os locais onde a característica passou a existir; e por fim, os locais que não sofreram alteração, mantendo a ocorrência da característica na segunda ocasião registrada. A do tipo múltipla estabelece a monitoria de alterações verificadas nas duas classes geradas pela monitoria simples, permitindo: indicar quais foram as categorias originais substituídas pela ocorrência da nova classe "tornou-se"; além de indicar quais as categorias que substituíram, no mapa mais novo, a classe "deixou de ser" (LAGEOP, 2007).

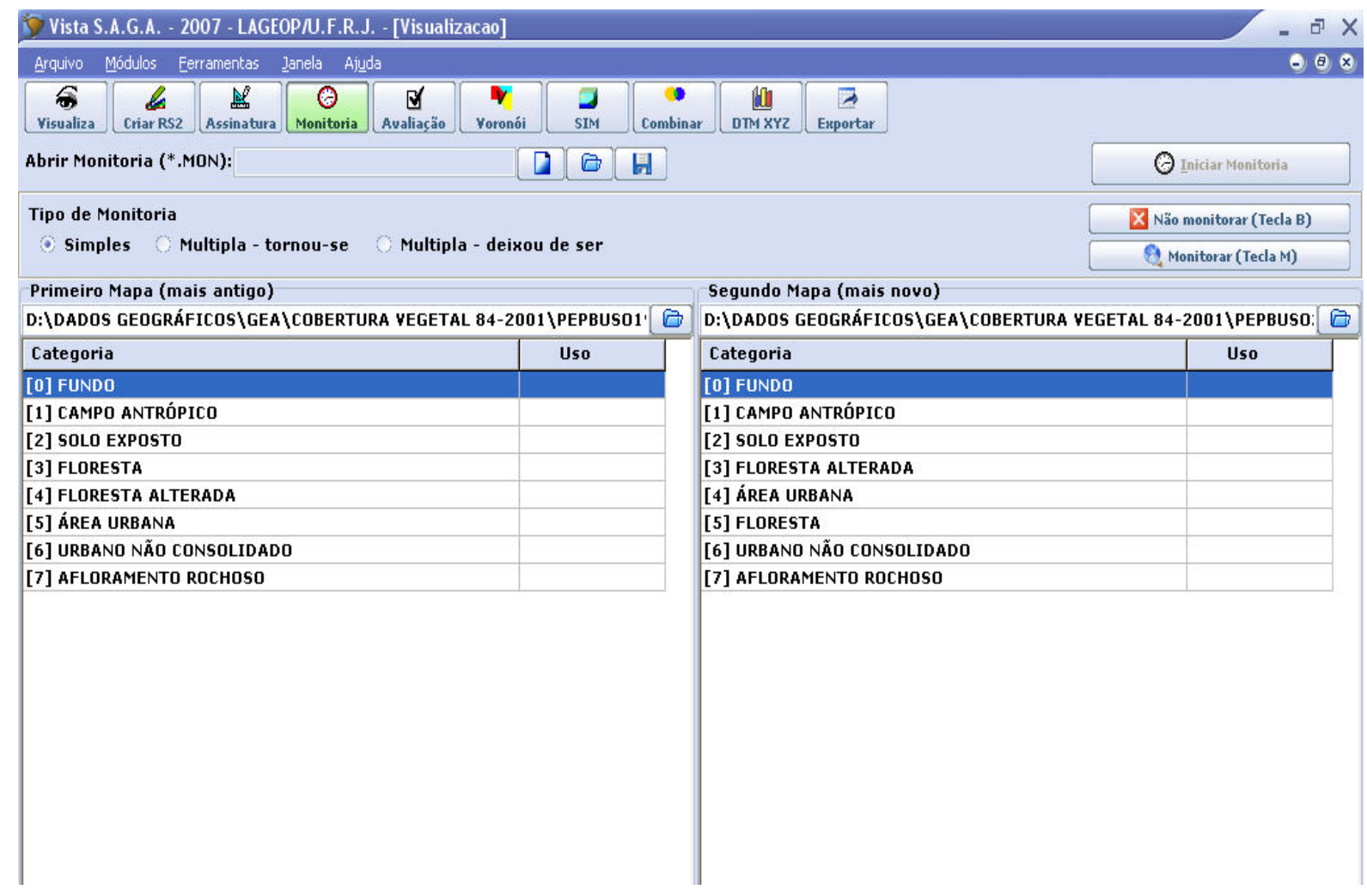

Figura 5 - Tela do Vista-SAGA: Função de monitoria simples, a partir das bases de uso do solo do PEPB em 1984 e 2001. 
A importância da evolução do uso do solo como geoindicador para o planejamento do Ecoturismo em Unidades de Conservação: aplicação no Parque Estadual da Pedra Branca (RJ).

A denominada assinatura ambiental permite a identificação da ocorrência conjunta de variáveis através de planimetrias (LAGEOP, 2007), ou seja, por intermédio desta função pôde-se cruzar determinados mapeamentos e obter percentuais de área das classes (Figura 6).

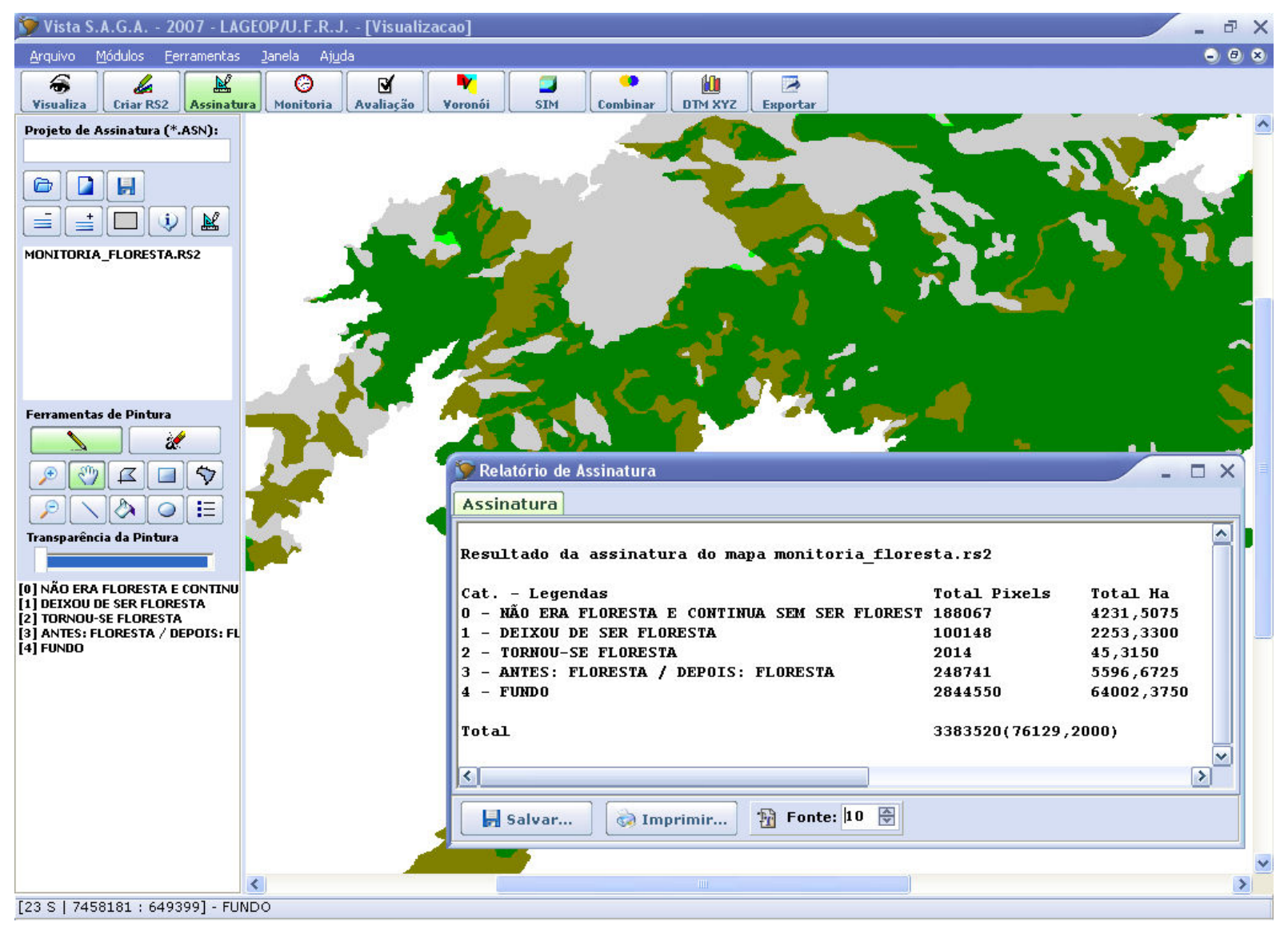

Figura 6 - Tela do Vista-SAGA: Função de assinatura ambiental, a partir do resultado da monitoria simples de uso do solo do PEPB em 1984 e 2001.

Buscando ainda identificar os principais focos de ocupação no interior e limites do Parque, recorreu-se ao aplicativo disponibilizado pela PCRJ através de seu site denominado "Armazém de Dados" (http://portalgeo.rio.rj.gov.br/sabren/index.htm), intitulado Sistema de Assentamentos de Baixa Renda - SABREN, o qual reúne e divulga informações sobre favelas e demais assentamentos irregulares e precários. Através da base cartográfica do IPP, bem como através do conhecimento empírico e de campo, foram listadas as principais favelas no PEPB e por fim, coletadas as informações de evolução da área (1999 - 2008), população e domicílios (2000) junto ao SABREN. 


\section{Resultados e discussão}

Primeiramente foram analisados os dados do mapeamento do uso do solo do PEPB. Conforme destacado no item medotologia, foram realizadas as análises a seguir descritas.

\section{Análise do geoindicador transformações do uso do solo (1984 a 2001)}

As classes de uso do solo identificadas na área do parque são: Floresta - Floresta ambrófila densa - Mata Atlântica, pouco ou não alterada. Pode também representar uma floresta secundária tardia; Floresta Alterada - Inclui diversas fitofisionomias associadas à alteração das florestas nativas, como raleamento por corte seletivo ou pequenas áreas de desmatamento, além de fases sucessionais que seguem a supressão total ou parcial da floresta nativa; Afloramento Rochoso - Inclui os afloramentos de rocha de origem natural; Área Urbana - Áreas densamente urbanizadas; Urbano Não Consolidado - Inclui áreas com ocupação humana esparsa, seja por estarem em processo de ocupação ou por serem áreas onde incidem limitações físicas ou legais para o processo de ocupação urbana; Campo Antrópico - Áreas de origem antrópica em sua quase totalidade. Ocorre principalmente em áreas marginais aos maciços constituindo regiões de transição entre áreas urbanas e ocupadas por florestas; Solo Exposto - Inclui áreas de solo exposto, seja por ocorrência de terraplanagem, deslizamentos ou pedreiras (PCRJ, 2000).

A assinatura dos mapas de uso do solo do PEPB em 1984, 1992 e 2001 permitiu um acompanhamento dos percentuais de área das classes em relação à área total do parque (Quadro 1). Observa-se um aumento significativo da classe de campo antrópico e diminuição da classe de floresta.

Quadro 1 - Percentuais de área das classes de uso nos anos de 1984, 1992 e 2001 do PEPB.

\begin{tabular}{|c|c|c|c|}
\hline Classes / Anos & $\mathbf{1 9 8 4}$ & $\mathbf{1 9 9 2}$ & $\mathbf{2 0 0 1}$ \\
\hline Área urbana & $0,00 \%$ & $0,00 \%$ & $0,01 \%$ \\
\hline $\begin{array}{c}\text { Urbano não consoli- } \\
\text { dado }\end{array}$ & $0,23 \%$ & $0,40 \%$ & $0,81 \%$ \\
\hline Campo antrópico & $19,13 \%$ & $20,05 \%$ & $28,48 \%$ \\
\hline Solo exposto & $0,55 \%$ & $0,81 \%$ & $0,18 \%$ \\
\hline Floresta & $64,56 \%$ & $60,10 \%$ & $46,52 \%$ \\
\hline Floresta alterada & $14,81 \%$ & $17,95 \%$ & $23,31 \%$ \\
\hline Afloramento rochoso & $0,68 \%$ & $0,66 \%$ & $0,66 \%$ \\
\hline
\end{tabular}


A importância da evolução do uso do solo como geoindicador para o planejamento do Ecoturismo em Unidades de Conservação: aplicação no Parque Estadual da Pedra Branca (RJ).

Através da monitoria (entre os anos de 1984 e 2001) da classe de uso "Floresta" (Figura 7), constatou-se um percentual de alteração de cerca de 19\% (sendo $18,58 \%$ de áreas que deixaram de ser floresta, e 0,37\% de reposição da área florestada). Cabe destacar que, do percentual de área que deixou de ser floresta em relação ao total da área, os principais destinos finais da classe foram os de "floresta alterada" (13,86\%) e "campo antrópico" (4,52\%) - Figura 3.

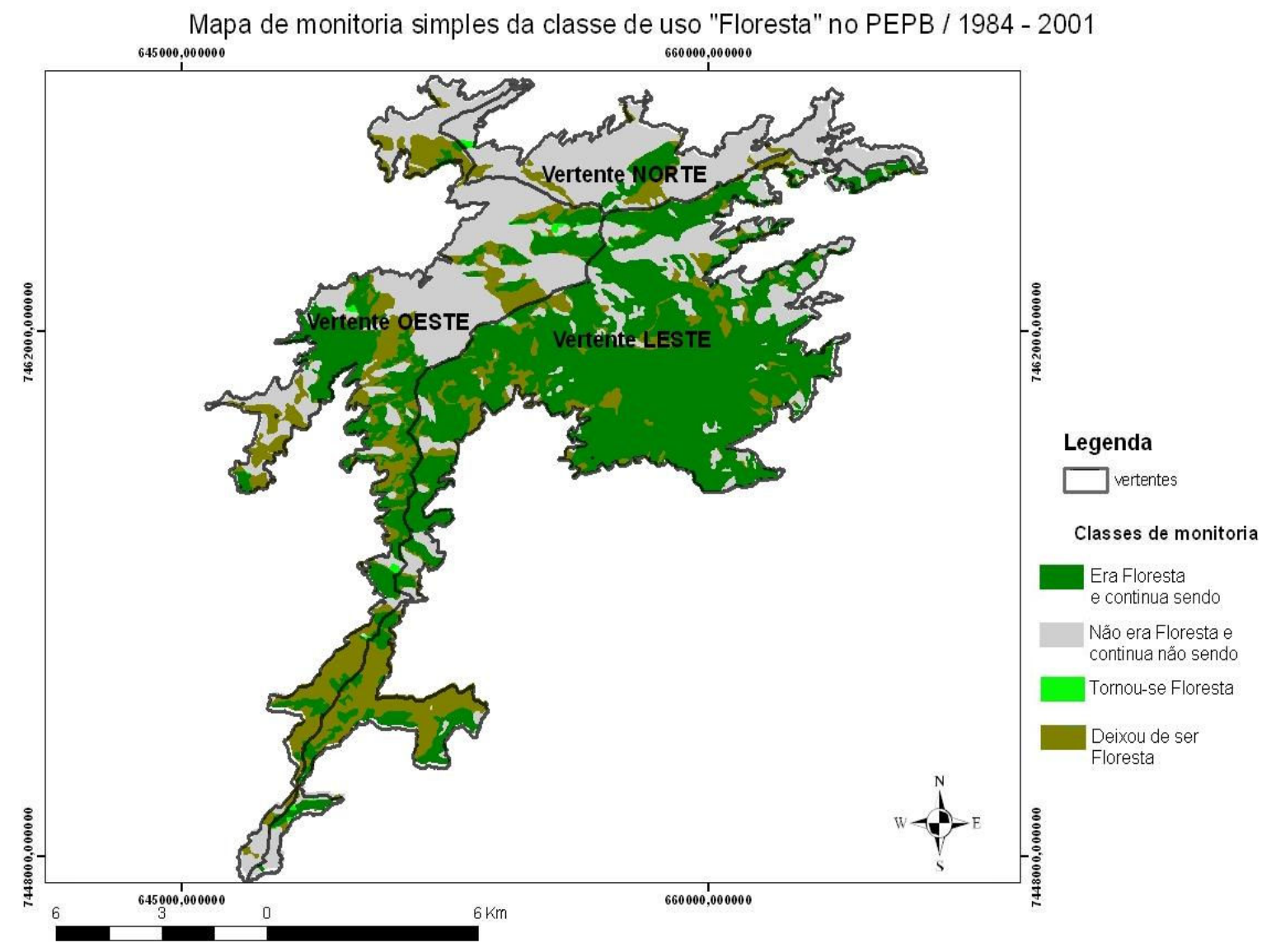

Figura 7 - Mapa de monitoria simples no PEPB (período de 1984 - 2001).

Base de dados de uso do solo IPP.

Espacialmente, grande parte das alterações está concentrada ao sul do PEPB (Figura 2), tanto na vertente leste como na oeste. Nesta área verifica-se atualmente 0 processo de substituição da vegetação nativa por cultivos (a exemplo das bananeiras). Na verdade, o cultivo da banana encontra-se entremeado à vegetação nativa, mascarando a prática ilegal dessa atividade agrícola. Com base nisto há uma divergência em relação ao mapeamento do uso do solo atual. Esta área deve ser considerada como floresta alterada ou de cultivo? É a questão que se impõe aos órgãos ambientais competentes da cidade e diretamente relacionados à gestão do Parque. Esta 
dificuldade pode ser superada por meio da ida de equipes a campo para determinar melhor os nomes das classes de uso do solo, de acordo com a realidade espacial'1.

As alterações também se relacionam à questão da ocupação antrópica. As áreas que deixaram de ser "floresta", e estão qualificadas como "campo antrópico" e "urbano não consolidado", estão distribuídas por toda extansão territorial do PEPB (Figura 8). Tais áreas, possivelmente, abarcam as mais variadas formas de ocupação: moradias de baixa a alta rendas, ou outros usos antrópicos, mais concentrados ou esparsados.

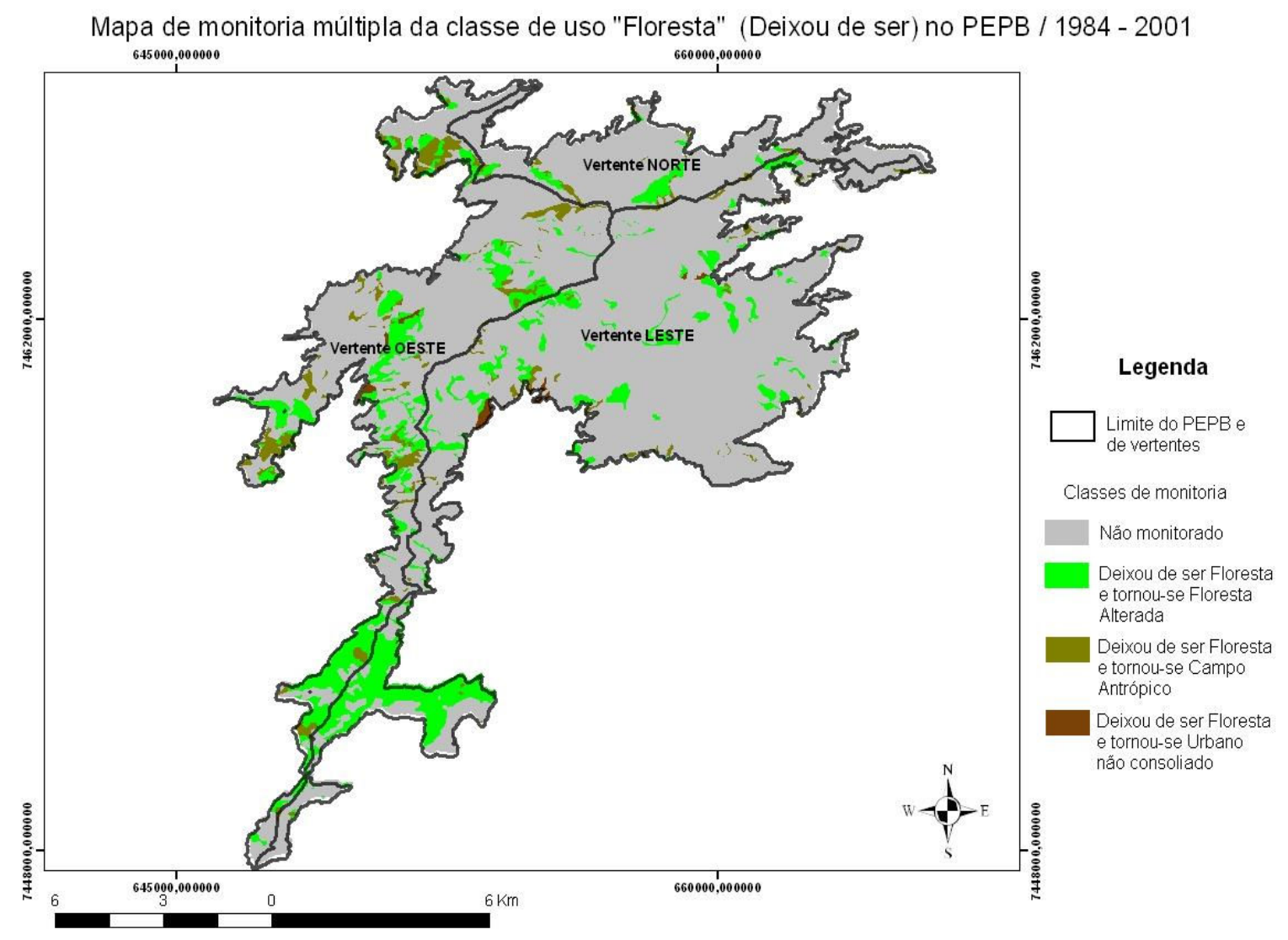

Figura 8 - Mapa de monitoria múltipla no PEPB (período de 1984 - 2001).

Base de dados de uso do solo IPP.

Com base no levantamento das informações relacionadas à ocupação irregular de baixa renda no interior e entorno do PEPB junto ao SABREN, revela-se uma expansão das áreas ocupadas. De um total de 16 favelas identificadas com áreas dentro do limite do parque, 7 estão distribuídas na vertente norte, 6 na leste e 3 na oeste. Com destaque para a Chácara Flora (vertente leste) que possuía em 2008 uma área de cerca de $162.000 \mathrm{~m}^{2}$, maior que a área existente em 1999 (cerca de $143.000 \mathrm{~m}^{2}$ ), e 
A importância da evolução do uso do solo como geoindicador para o planejamento do Ecoturismo em Unidades de Conservação: aplicação no Parque Estadual da Pedra Branca (RJ).

uma população de mais de 2000 moradores no ano de 2000.

Pode-se destacar também a Comunidade da Pedra Branca (ou segundo o SABREN "Favela Parque da Pedra Branca") totalmente inserida no interior do Parque. Com um total de 102 domicílios em 2000, esta faixa de ocupação ampliou os seus limites territoriais no período de 2000 (Ortofoto do IPP, 2000) a 2008 (imagem de satélite pertencente ao LAGEPRO - Alos, 2008), conforme indica a Figura 9.

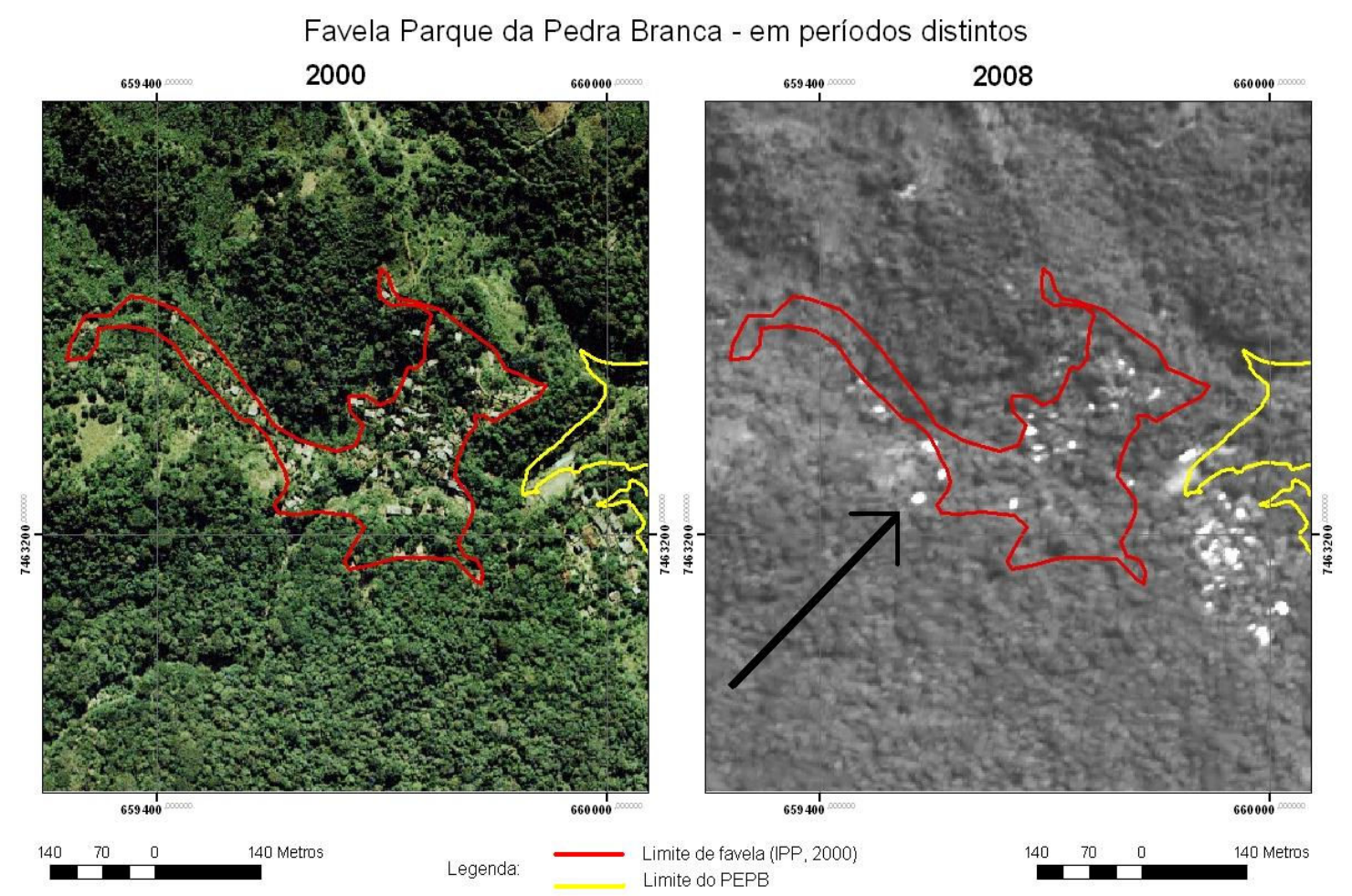

Figura 9 - Esquema de comparação visual do avanço territorial da Favela Parque da Pedra Branca no período de 2000 (Ortofoto - IPP) e 2008 (ALOS - LAGEPRO).

Limite de favelas - Base de dados IPP (2000).

\section{Análise sobre o geoindicador uso do solo confrontado com os atrativos ecotu- rísticos do PEPB}

A distribuição dos atrativos no PEPB ocorre, predominantemente, em ambientes de florestas, localizados nas vertentes mais internas do maciço e naquelas mais próximas da área de baixada na AP 4 (Figura 10). Os mirantes (atrativos para a contemplação da paisagem), estão distribuídos do centro ao leste do Parque. Os atrativos naturais (cachoeiras, açudes e pontos ao longo de rios e trilhas que apresentam belezas naturais que podem ser apreciadas pelo visitante) e histórico-culturais (museus, aquedutos de abastecimento de água e construções de patrimônio histórico-cultural) concentram-se na vertente leste. 
Através do cruzamento entre os mapas constata-se que, no PEPB, a maioria das áreas de atrativos (42,86\%) encontra-se na categoria de uso "Floresta", seguida por "Floresta Alterada" e "Campo antrópico" (abarcando estas duas classes cerca de 40\% da área de buffer de atrativos).

Tal situação indica que, para o planejamento do ecoturismo no PEPB, a partir do conhecimento da área dos atrativos catalogados em que a prática ocorre efetivamente (ou não) e de áreas com alto potencial, deve-se levar em consideração as alterações no uso do solo ocorrentes nos últimos anos.

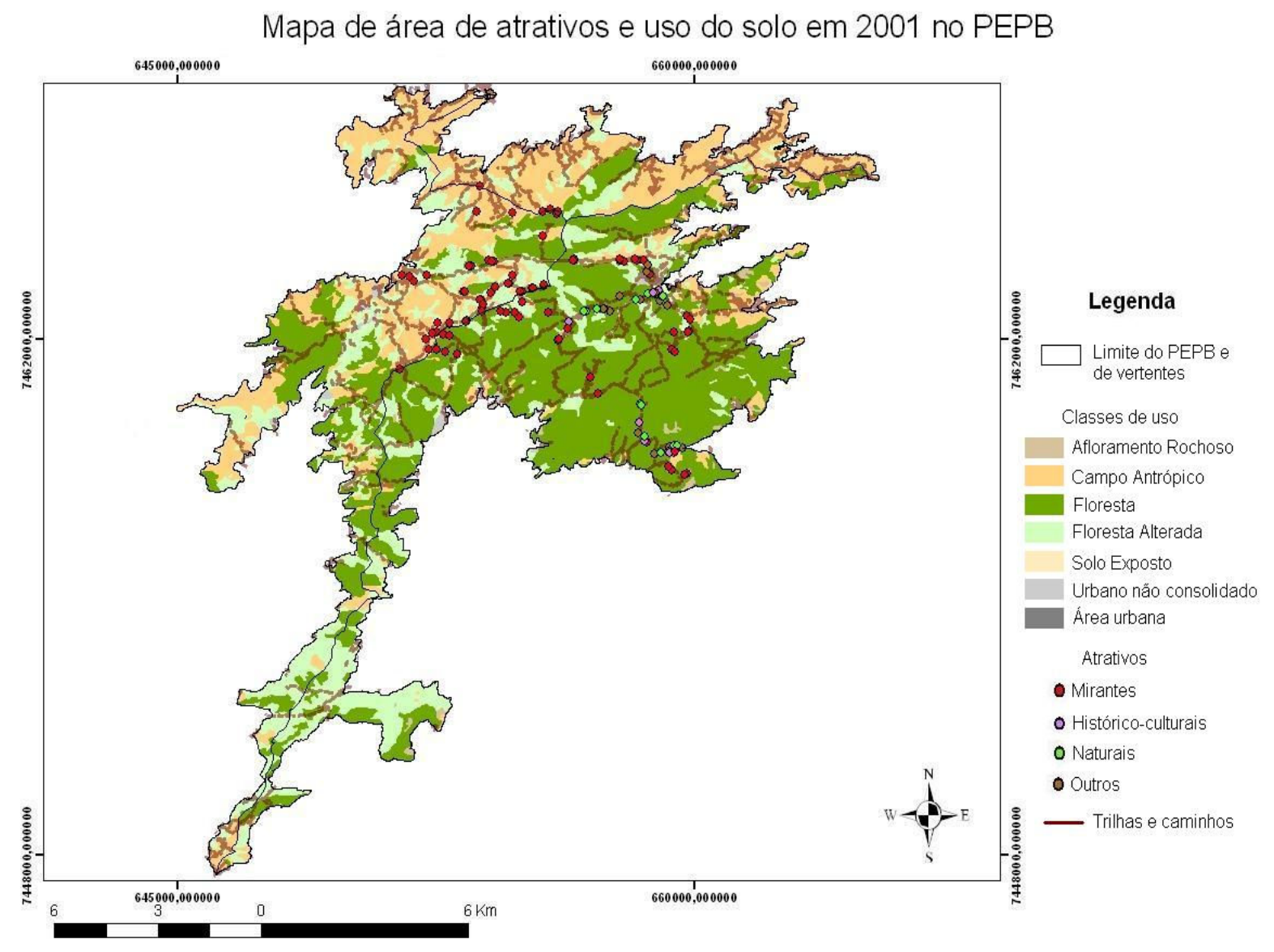

Figura 10 - Mapa de área de atrativos e uso do solo em 2001.

Base de dados de uso do solo IPP; levantamento de atrativos realizado pelo GEA (Grupo de Estudos Ambientais) em 2008.

Desta forma, o ecoturismo deve ser planejado pelos gestores do Parque de forma a detectar possíveis áreas de reflorestamento e/ou de conflito sócio-ambiental. No processo de gestão do uso público, ações efetivas de educação ambiental contando com a participação da população local (moradores do interior e próximo à UC), deverão ocorrer a fim de alcançar o que preceitua o ecoturismo. Todos os principais atores sociais deverão es- 
A importância da evolução do uso do solo como geoindicador para o planejamento do Ecoturismo em Unidades de Conservação: aplicação no Parque Estadual da Pedra Branca (RJ).

tar engajados, de maneira articulada, pelos órgãos públicos, ONGs e empresas (empreendedores do trade turístico) no planejamento e implementação das atividades ecoturísticas no PEPB.

\section{Conclusões}

O geoindicador de evolução do uso do solo apresenta-se como um indicador relacionado à atividade antrópica de valiosa contribuição ao entendimento dos processos de pressão urbana e alterações no uso do solo no PEPB. Quando cruzado com parâmetros relacionados ao (eco)turismo, se mostra uma importante ferramenta para o entendimento do estado atual de conservação do Parque e para a caracterização do cenário de desenvolvimento das atividades a ele relacionadas.

O PEPB, por se tratar de uma unidade de conservação urbana, merece especial atenção no que diz respeito a necessidade de monitoramento das alterações de uso e ocupação em seu interior, particularmente aquelas associadas aos seus atrativos naturais destinados a visitação e lazer.

O resultado da aplicação do geoindicador "evolução do uso do solo" mostrou que o percentual de área da categoria "Floresta" está abaixo (menos de 50\%) do valor de referência estabelecido como satisfatório para a manutenção de práticas de lazer e recreação na natureza. A perda significativa de áreas de uso do solo que concentram os principais atrativos ecoturísticos, serve de alerta às autoridades competentes, no sentido de preservar uma das mais importantes fontes de implementação do uso público relacionada a visitação de todo o PEPB: a Mata Atântica em seus diferentes estágios sucessionais.

Neste sentido, o geoprocessamento torna-se importante aliado no apoio à tomada de decisão por parte dos gestores de unidades de conservação, alinhando as políticas públicas de proteção dos fragmentos florestais urbanos aos interesses de preservação dessas áreas que hoje são importantes recursos naturais a serem explorados economicamente de forma sustentável pelas comunidades que vivem em seu entorno, principalmente para as atividades ecoturísticas, que vêm sendo a melhor forma de reduzir as desigualdades sociais e garantir alternativas de renda e melhora da qualidade de vida a esses importantes atores sociais.

\section{Referências Bibliográficas}

BELLEN, H. M. V. Indicadores de Sustentabilidade: Uma Análise Comparativa. Rio de Janeiro: ed. FGV, 2007.

BENI, M. C. Análise estrutural do turismo. São Paulo: Senac, 2001.

BERGER. A. R. Assessing Rapid Environmental Change Using Geoindicators. Environment Geology, Springer, Berlin, v. 1, n. 32, p. 35-44, 1997.

CÂMARA, G.; DAVIS, C.; MONTEIRO, A. M. V. Introdução à ciência da geoinformação. São José dos Campos: INPE, 2000.

CHRISTOFOLETTI, A. Modelagem de sistemas ambientais. 1. ed. São Paulo: Edgard Blucher, 1999. 
CINTRA, H. de B. Indicadores de sustentabilidade para o Ecoturismo e o Turismo Rural: uma proposta para Aldeia Velha, município de Silva Jardim - RJ e região do entorno. Dissertação (mestrado em Ciência Ambiental). Niterói: UFF, 2004. 127 p.

COSTA, N. M. C. da. Ecoturismo: abordagens e perspectivas geográficas. In: COSTA et al. (Org), Pelas trilhas do ecoturismo. Parte I. São Paulo: Ed. RIMA. p.17-30, 2008a.

COSTA, V. C. da. Planejamento ambiental de trilhas ecoturísticas em Unidades de Conservação no Brasil, utilizando geoprocessamento. In: COSTA et al. (Org). Pelas trilhas do ecoturismo. Parte III. São Paulo: Ed. RIMA. p. 147-167, 2008b.

COSTA, N. M. C. da; COSTA, V. C. da; CONCEIÇÃO, R. S. da; SANTOS, J. P. C.; ALVES, L. F.; OLIVEIRA, I. A. de; ASSIS, V. de; RIBEIRO, J. V. M.; CANANEA, D. de C. GeoIndicadores de desenvolvimento sustentável do ecoturismo: sua importância no manejo dos recursos naturais em Áreas Protegidas brasileiras. Anais do XII Encuentro de Geógrafos de América Latina - EGAL, Montevideo, CD-ROM. 2009. Disponível em: http:// egal2009.easyplanners.info/area07/7117_Costa_Nadja_Maria_Castilho_da.doc. Acessado em: 30 de julho de 2010.

FILLETO, F. Desenvolvimento de indicadores de sustentabilidade para o ecoturismo em unidades de conservação. Tese (doutorado Engenharia Florestal). Lavras: UFLA, 2007. 145p.

HORTA, C.; AYRES, H. H. F.; ALEGRIA, M. F.; IRVING, M. A. Parque Estadual da Pedra Branca: A maior floresta urbana protegida do Brasil. In: IRVING, M. A.; GIULIANI, G. M; LOUREIRO, C. F. (Org). Parques Estaduais do Rio de Janeiro: Construindo novas práticas para a gestão. São Carlos: Ed. RIMA. p. 97-107, 2008.

IBGE. Indicadores de desenvolvimento sustentável. Instituto Brasileiro de Geografia e Estatística - IBGE. R. de Janeiro - Brasil. 471 p. 2008.

LAGEOP - LABORATÓRIO DE GEOPROCESSAMENTO. Manual Operacional do Programa Vista SAGA. Rio de Janeiro: LAGEOP / UFRJ, 2007.

MARINO, T. B. Vista Saga 2005: Sistema de Análise Geo-Ambiental. Monografia (Graduação em Ciência da Computação). Rio de Janeiro: Instituto de Matemática, UFRJ, 2005. 72 p.

PCRJ - PREFEITURA DA CIDADE DO RIO DE JANEIRO. Mapeamento e Caracterização do Uso das Terras e Cobertura Vegetal no Município do Rio de Janeiro entre os anos de 1984 e 1999. Rio de Janeiro: PCRJ - Secretaria Municipal de Meio Ambiente, 2000.

REGO NETO, C. B. A Integração de Geoindicadores e Reparcelamento do Solo na Gestão Ambiental Urbana. Tese (doutorado em Engenharia de Produção). Florianópolis: UFSC, 2003. $231 \mathrm{p}$.

RIBEIRO, M. A. Ecologizar: Pensando o ambiente humano. Belo Horizonte: Rona, 1998.

SANTOS, R. F. dos. Planejamento ambiental: teoria e prática. São Paulo: Oficina de Textos, 2004.

TAVARES, A. B. et al. Geoindicadores para a caracterização de estado de diferentes ambientes. Estudos Geográficos. Rio Claro, 5(2): 42-57, 2007.

XAVIER-DA-SILVA, J. Geoprocessamento para Análise Ambiental. Rio de Janeiro: Edição do Autor, 2001. 
A importância da evolução do uso do solo como geoindicador para o planejamento do Ecoturismo em Unidades de Conservação: aplicação no Parque Estadual da Pedra Branca (RJ).

\section{NOTA}

1 Observa-se a necessidade de detalhamento na caracterização do uso do solo, atualização do mapeamento e ampliação dos dados de ocupação de baixa e alta renda na região de entorno e interior do parque, em ação conjunta entre os órgãos gestores, detentores das informações e pesquisadores afins para futuras tomadas de decisão. O Grupo de Estudos Ambientais (GEA) pretende realizar a atualização do mapeamento de uso do solo no PEPB a partir das bases vetoriais de uso do solo do IPP e da imagem de satélite ALOS (2008), no qual deverão ser refinados os nomes das categorias de acordo com a realidade do Parque, pautando-se em trabalhos desenvolvidos ao longo do tempo, na área.

\section{Agradecimentos:}

Ao Laboratório de Geoprocessamento - LAGEPRO do Instituto de Geografia da UERJ, pela utilização da infra-estrutura e viabilidade da pesquisa; ao Instituto Pereira Passos - IPP pela cessão de bases de dados de uso do solo ao LAGEPRO; ao Núcleo de Estudos e Pesquisas em Geoprocessamento - NEPGEO, pela utilização da licença do programa ARCGIS 9.0.

\section{Apoio Financeiro:}

IPGH - Instituto Panamericano de Geografia e História; FAPERJ - Fundação de Amparo à Pesquisa do Estado do Rio de Janeiro (Projeto APQ1); CNPq (Bolsa de Produtividade em Pesquisa - Nadja M. Castilho da Costa).

Rodrigo Silva da Conceição: Universidade do Estado do Rio de Janeiro.

Email: rsc_geo@yahoo.com.br

Link para o currículo Lattes: http://lattes.cnpq.br/6765553122333119

Nadja Maria Castilho da Costa: Universidade do Estado do Rio de Janeiro.

Email: nadjacastilho@oi.com.br

Link para o currículo Lattes: http://lattes.cnpq.br/8646672305430213

Vivian Castilho da Costa: Universidade do Estado do Rio de Janeiro.

Email: vivianuerj@gmail.com

Link para o currículo Lattes: http://lattes.cnpq.br/3181407490194397

Data de submissão: 03 de novembro 2009.

Data do aceite: 16 de julho de 2010. 